\title{
THE MANY PROBLEMS OF SPECIAL DIVINE ACTION
}

\section{BENEDIKT PAUL GÖCKE}

\author{
University of Oxford
}

\begin{abstract}
Special divine action is an integral part of the Christian worldview. In fact, the plausibility of the Christian worldview depends on and is grounded in the putative reality, and therefore possibility, of special divine action. Without special divine action, Scripture does not make sense, and without Scripture, Christianity neither. However, the possibility of special divine action is highly contested in almost every field of human enquiry. In what follows, I briefly suggest a minimal definition of special divine action and show its indispensability for the internal plausibility of Christian faith. I then argue against the very possibility of special divine action. I end by way of identifying ways in which Christian theologians can respond to the arguments in order to justify the possibility of special divine action. It turns out that special divine action neither contradicts science nor metaphysics.
\end{abstract}

Special divine action is an integral part of the Christian worldview. ${ }^{1}$ In fact, the plausibility of the Christian worldview depends on and is grounded in the putative reality, and therefore possibility, of special divine action. Without special divine action, Scripture does not make sense, and without Scripture, Christianity neither. However, the possibility of special divine action is highly contested in almost every field of human enquiry. In what follows, I briefly suggest a minimal definition of special divine action and show its indispensability for the internal plausibility of Christian faith. I then argue against the very possibility of special divine action. I end by way of identifying ways in which Christian theologians can respond to the arguments in order to justify the possibility of special divine action. It turns out that special divine action neither contradicts science nor metaphysics.

${ }^{1}$ Of course, in making this claim I do not wish to exclude the importance of special divine action for other religions like Judaism or Islam. Christian faith, though, is a particularly rich tradition concerning the analysis of special divine action. 


\section{THE INDISPENSABILITY OF SPECIAL DIVINE ACTION}

Here are some assumptions I take for granted: First, a state of affairs $S$ is constituted by a particular $\mathrm{p}$, a property $\mathrm{F}$ and a point of time $\mathrm{t}$. The obtaining of $S$ at $t$ consists in p's exemplifying $F$ at $t$. Second, a possible world $\mathrm{w}$ is a maximally consistent state of affairs. Third, the history $\mathrm{h}$ of a possible world $\mathrm{w}$ at $\mathrm{t}$ is the temporally ordered class of all states of affairs that obtain in $\mathrm{w}$ prior to and including t. A future $\mathrm{f}$ of a possible world $\mathrm{w}$ is the temporally ordered class of all states of affairs that obtain posterior to t. Fourth, the actual world @ is the only obtaining maximal consistent state of affairs. Fifth, as the purpose of this paper is to analyse the possibility of special divine action and not to argue for the existence of God per se, I assume that the existence of the actual world is contingent and presupposes an ultimate and supernatural ground of its existence that properly is referred to as 'God'.'

\section{General and Special Divine Action}

I assume the following minimal definition of general divine action: $G$ is a general divine action if and only if $\mathrm{G}$ is an action that God engages in at every moment of existence of the actual world. The very existence of the actual world, therefore, is the effect of God's general action: out of the infinity of possible worlds, God chooses one world to be the actual world by way of holding it in existence at every point of time of its existence. Without God's general action, the actual world would not exist. ${ }^{3}$ In contrast to general divine action, special divine action could, in a first attempt, be defined as follows: $\mathrm{A}$ is a special divine action if and only if A is God's actualisation of a particular state of affairs $S$ at some point of time $t$ in the actual world.

However, based on the proposed definitions we obtain the following problem: if general divine action consists in God's actualizing a possible world, then God is eo ipso causally responsible for the obtaining of each and every state of affairs $S$ in the actual world. After all, a possible world

\footnotetext{
${ }^{2}$ Cf. Mautner (1996: 416). For an analysis of the different ways in which the term "God" is used, and for an analysis of the structure of arguments for and against the existence of God, see Göcke (2013). For further analysis of the ontology of possible worlds cf. Göcke (2014a).

${ }^{3}$ Cf. Kraay (2008) for an argument to the effect that God cannot be the creator of the world because God neither has a sufficient reason to create a particular world instead of another nor is able to rely on a randomizing device in order to chose which world to create.
} 
is nothing over and above a maximal consistent state of affairs: in order to actualise a possible world w, God has to actualise every state of affairs $\mathrm{S}$ that constitutes $\mathrm{w}$. It follows that in the situation at hand the concept of special divine action is absorbed by the concept of general divine action. Occasionalism follows immediately since God would be the only acting agent.

In order to be able to distinguish between general and special divine action (and in order to avoid occasionalism), we have to find a way of understanding special divine action as something in addition to God's general action of actualising every state of affairs that is part of the actual world. To do so, we have to assume that God's general action of creating the world is such that it bestows autonomy to the actual world, i.e. a tendency to stay in existence and to direct itself. ${ }^{4}$ More technically, although God's general action holds the world in existence at every point of time, it is nevertheless true that for each point of time $t$ of the actual world, there is a future f of @ that is accountable purely in terms of the history of @ at t. ${ }^{5}$

Based on the assumption of an autonomous world, we can formulate the following minimal definition of special divine action: $\mathrm{A}$ is a special divine action if and only if A is God's supernatural actualisation of a state of affairs $S$ at $t$ the obtaining of which was not entailed by the history $h$ of @ at $t$, whereas $S$ is not entailed by $h$ if and only if there is a future $f$ of the actual world in which $S$ does not obtain. This definition is minimal because any account of special divine action - no matter which further conditions it imposes on special divine action - has to presuppose that a special divine action at least has the features suggested. ${ }^{6}$

\section{Interventionist and Non-Interventionist Accounts of Special Divine Action}

We can specify the relation between general and special divine action as follows: God's general action is God's creation of an autonomous world, and if there is special divine action, then at least sometimes God supernaturally actualises a state of affairs $S$ at $t$ the obtaining of which was not entailed by the prior history of the actual world up to

${ }^{4}$ This is, of course, what Thomas had in mind when he distinguished between primary and secondary causes. See, for instance, Thomas' Summa Theologica, 1q 105 and Griffin (2014: 56/57)

${ }^{5}$ For an analysis of occasionalism, cf. Perler/Rudolph (2000), Clayton (2008: 120) and Murphy (1995: 332).

${ }^{6}$ Cf. Alston (1999: 185) and Schwöbel (1992: 36). 
and including t. Like a piano player whose left hand constantly plays the same chord, God's special divine actions can be seen as his right hand adding now and then some fine tunes in order to create the overall melody of creation.

Recently a distinction was introduced between so-called interventionist and non-interventionist accounts of special divine action. The distinction, however, is dim and hard to justify. It often seems to be entirely artificial. Here is why: non-interventionists suppose that the ontological gaps associated with some metaphysical interpretations of modern scientific theories, like chaos theory or quantum mechanics, provide a legitimate loophole for God to act in a way that is consistent with the development of the natural order itself. ${ }^{7}$ In contrast, interventionism is said to entail that God's special actions are violations of the natural order of causes. ${ }^{8}$ This, though, only follows on the further assumption that interventionism, in contrast to non-interventionism, is committed to a deterministic interpretation of the natural order of causes. ${ }^{9}$ Without this assumption, the distinction between non-interventionism and interventionism collapses. Since interventionism is not committed to a deterministic interpretation of the natural order of causes it follows that the distinction between interventionism and non-interventionism is without support. In fact, even if there was a substantial difference, both interpretations presuppose the suggested minimal definition of special divine action. On both accounts, a special divine action is a supernatural intervention in the actual world that actualises a state of affairs $S$ at $t$ the obtaining of which was not entailed by the history of the actual world up to and including t. ${ }^{10}$

\section{The Indispensability of Special Divine Action for Christian Faith}

Special divine action is indispensable for Christian faith. The Bible is full of references that depict God as actively involved in the history and fate of His people by way of actualizing particular states of affairs the obtaining of which was not entailed by the prior history of the world. Just to mention two prominent examples:

\footnotetext{
${ }^{7}$ Cf. Wegter-McNelly (2009: 162-163).

${ }^{8}$ Cf. Wegter-McNelly (2009: 161).

${ }^{9}$ Cf. Ward (2007: 119).

${ }^{10}$ Cf. for instance, Murphy (1995: 342).
} 
First, the separation of the Red Sea is described as follows:

Then Moses stretched out his hand over the sea; and the LORD drove the sea back by a strong east wind all night, and made the sea dry land, and the waters were divided. And the people of Israel went into the midst of the sea on dry ground, the water being a wall to them on their right hand and on their left. [...] Then the LORD said to Moses, 'Stretch our your hand over the sea, that the water may come back upon the Egyptians, upon their chariots, and upon their horsemen.' So Moses stretched forth his hand over the sea, and the sea returned to its wonted flow when the morning appeared, and the Egyptians fled into it, and the LORD routed the Egyptians in the midst of the sea.' (Exodus 14, 21-27)

It is clear that in this passage God is described as engaging in special divine action: God actualises a state of affairs - the separation of the Red Sea - that otherwise had not occurred and that was not accountable for in terms of the history of the actual world up to that point of time. Furthermore, God did so on purpose, in order to save His people, and the impossibility of special divine action would destroy the very reliability of Scripture as a story of God's loving relation to His people.

Second, assuming that the resurrection of Christ is the paradigmatic special divine action, the New Testament itself is as clear as one could wish that the possibility of special divine action is a necessary condition for the plausibility of Christian faith. As Paul argues:

Now if Christ is preached as raised from the dead, how can some of you say that there is no resurrection of the dead? But if there is no resurrection of the dead, then Christ has not been raised; if Christ has not been raised, then our preaching is in vain and your faith is in vain. We are even found to be misrepresenting God, because we testified of God that he raised Christ, whom he did not raise if it is true that the dead are not raised. For if the dead are not raised, then Christ has not been raised. If Christ has not been raised, your faith is futile and you are still in your sins. Then those also who have fallen asleep in Christ have perished. If for this life only we have hoped in Christ, we are of all men most to be pitied.' (1 Corinthians 15. 12-19)

Paul explicitly states with logical rigour that without the resurrection of Christ, Christian faith is in vain and those who follow Christ are to be pitied. 
Therefore, since 'from the call of Abraham and the Exodus from Egypt to the birth, ministry, death, and raising of Jesus and the founding of the church at Pentecost, God is represented as making new things happen' (Russell 1998: 191) we can conclude that special divine action is an indispensable part of Christian faith itself: if special divine action is impossible, then there is no point in being a Christian at all. ${ }^{11}$

\section{THE IMPOSSIBILITY OF SPECIAL DIVINE ACTION}

There are several arguments against the possibility of special divine action. In what follows, I ignore basic arguments that are directed against the existence of God, or against the intelligibility of the very idea of a God acting in history. Although it is an important task for Christian philosophers to argue for the existence of God, I focus on arguments that show that even if there is no conceptual problem with an acting God as such, special divine action is nevertheless impossible.

\section{The Argument from Causal Closure}

The first argument against the possibility of special divine action is based on the assumption that the actual world is a causally closed system that excludes any non-physical intervention. Although there are different versions of causal closure discussed, the general idea is that the actual world is causally closed because every obtaining state of affairs $S$ has a purely physical causal history that is responsible for S's obtaining. As Clayton (2008: 135) says, 'a basic assumption of many modern physicists is that physical systems are closed to causal interventions from outside (the principle of the conservation of energy). ${ }^{12}$ In case of determinism, causal closure states that there is a sufficient physical causal history for every obtaining state of affairs. In case of indeterminism, causal closure 'would say that the chances of physical effects are always fully fixed by their prior physical histories' (Papineau 2002: 17 FN). ${ }^{13}$

Since a special divine action is a supernatural, and therefore a nonphysical intervention in the actual world we obtain the following conclusion: if the actual world is causally closed, then special divine

\footnotetext{
${ }^{11}$ Cf. Cobb (1973: 207).

${ }^{12}$ Cf. Papineau (2002: 17), Papineau (2000), Göcke (2008) and Lowe (2008).

${ }^{13}$ Cf. Plantinga (2011: 92-93).
} 
action is impossible. It would be a supernatural actualisation of a state of affairs $S$ the causal history of which was not completely physical. As it were, God pushed too hard on the autonomy of the actual world and created a world that at any point of time thas a future that is accountable for purely in terms of the world's history. Therefore, since the actual world is causally closed, special divine action is impossible. As Saunders (2000: 518 ) says: 'The causally closed view of science in which every event leads to another seems to many to leave no room for God at all.' ${ }^{14}$

\section{The Argument from Determinism}

The second argument against the possibility of special divine action does not focus on the causally closed nature of the actual world. Instead it assumes that independent from whether a supernatural intervention as such is possible, special divine action is impossible for quite another reason: it is impossible because the actual world is a deterministic world.

Determinism entails that there are no two possible worlds $\mathrm{w}$ and $\mathrm{w}^{*}$ that share the same history $\mathrm{h}$ at $\mathrm{t}$ but differ in respect to their future $\mathrm{f}$. In a deterministic world $\mathrm{w}$, the history at $\mathrm{t}$ can be addressed as the sufficient cause of the future of w. As Schaffer (2007: 115) states: 'A world $w$ is deterministic iff: for all times $t$ in $w$, the total occurent history of $w$ supervenes on the occurent state of $w$ at $t$ together with the laws of w. ${ }^{15}$ Since a special divine action is God's actualisation of a state of affairs $S$ that was not entailed to obtain by the history of the world at any arbitrarily chosen point of its history prior to S's obtaining, it follows that special divine action is impossible because the actual world is a deterministic world.

\section{The Argument from Laws of Nature}

A third argument against the possibility of special divine action is based on the assumption that the possibility of special divine action contradicts the intelligibility of the world because it contradicts the existence of the laws of nature - no matter whether these are thought of as deterministic or indeterministic. Although the discussion concerning the semantics and ontology of the laws of nature is far from being unanimous, Craver provides a useful summary of some of the most important features

\footnotetext{
${ }^{14}$ Cf. also Pollard (1958: 12).

${ }^{15}$ Cf. also Earman (1986: 13) and Laplace (1951: 4)
} 
of what the laws of nature are supposed to be. They are '(1) logically contingent, (2) true (without exception), (3) universal generalisations, that are (4) unlimited in scope and (5) hold by physical necessity' (Craver 2007: 56-57). The laws of nature thus understood enable us to explain the past and to predict the future. They are what accounts for the intelligibility of the actual world.

However, if special divine action is possible, then no laws of nature can exist because in this case there is no exceptionless and true universal generalisation that accounts for the history and the future of the actual world. As a consequence, the way the world works would remain unintelligible to us because God could intervene at arbitrary points of time in the future, and could have done so in the past. Therefore, if special divine action is possible, laws of nature are impossible. Since there are laws of nature, it follows that special divine action is impossible.

\section{The Argument from Scientific Evidence}

A fourth argument is not directed against the possibility, but against the actuality of special divine action. It is based on the following assumption: if the obtaining of a state of affairs $S$ at $t$ is due to special divine intervention, then there has to be scientific evidence that $S$ is due to divine intervention. There is no scientific evidence, however, for any kind of divine intervention in the actual world. As Papineau (2002: 253) argues, 'detailed modern research has failed to uncover any [...] anomalous physical processes. [...] If there were such [non-physical] forces, they could be expected to display some manifestation of their presence. But detailed [...] investigation failed to uncover evidence of anything except familiar physical forces.' Therefore, based on the absence of scientific evidence, we have to conclude that there is no special divine action: if there was, science would by now have told us. As Clayton (2008: 219) says, 'scientific research has not provided evidence that God did, or does, bring about miracles in the natural world. [...] Worse, the basic methodology of science seems to stand opposed to even the possibility of such events.'

\section{The Argument from Evil}

A last argument against the possibility of special divine action is based on the assumption that there is a huge amount of unnecessary and thus purposeless evil and suffering in the world. However, if God exists and is 
able to act in the world, and if God is omniscient, morally perfect, and omnipotent, then $\mathrm{He}$ is morally obliged to intervene in order to prevent unnecessary evil and suffering in the world. This, though, is not what we observe: God does not prevent unnecessary evil and suffering. ${ }^{16}$ The best explanation for this fact is that - for whatever reason - God simply cannot act in the world. If He could, He would. Therefore, given the huge amount of unnecessary suffering and evil in the world, it follows that God cannot act in the world.

\section{There is no Point in Being a Christian}

God cannot create a world that is self-directed while at the same time open to supernatural intervention. Even if He could create such a world, the apparent amount of unnecessary suffering and evil shows that for whatever reason God cannot act in the actual world in order to prevent unnecessary evil and suffering. Since the possibility of special divine action is an indispensable part of Christian faith, there is no point in being a Christian.

\section{SPECIAL DIVINE ACTION AND THE CHRISTIAN WORLDVIEW}

In what follows I indicate ways in which the above arguments can be criticised from a Christian point of view. ${ }^{17} \mathrm{~A}$ first and general point to be noted concerns the relation between special divine action and human free action, understood in a libertarian sense. Since apart from the argument from evil, each argument not only entails the impossibility of special divine action, but also the impossibility of libertarian free human action, it follows that any theistic metaphysics allowing for free human action also allows for special divine action. In a theistic paradigm, human free action is possible if and only if special divine action is possible.

\section{Causal Closure Reconsidered}

Although the causal closure of the actual world is an often-met assumption in the philosophy of mind and philosophy of religion, it is by no means an uncontroversial assumption. First of all, causal closure itself is not a metaphysically necessary assumption, and it is neither a scientific

${ }^{16}$ Cf. Clayton (2008: 218).

${ }^{17}$ Cf. Göcke (2014b). 
assumption: it is neither a consequence, nor a presupposition of science itself. Instead, it is a philosophical assumption that belongs to an atheistic and naturalistic worldview. Science might as a methodological restraint suppose that it should look for physical causal histories whenever it wants to explain the obtaining of a particular state of affairs, but as soon as scientists assume that it is a metaphysical principle that there can only be physical causes, they leave the realm of science and enter metaphysical territory. As Polkinghorne (2006: 67) argues, 'it is clear that physical closure of the causal nexus of the world has not been established, so that claims that science has disproved the possibility of providential agency can be seen to be false. Belief in divine action is no more necessarily negated by an honest science than is belief in free human agency.'

\section{Determinism Reconsidered}

In order to refute the argument from determinism one has to show that the actual world is not a deterministic world. In order to do so, we can rely on two sources: first we can rely on arguments according to which human beings can engage in rational discussion. Since the very idea of rational argumentation presupposes that determinism is false, and since any argument for determinism presupposes the possibility of rational argumentation, it follows that determinism is transcendentally selfrefuting. Second, although there is an often-mentioned relation between classical physics and determinism, we can rely on recent developments in physics that presuppose that the actual world is an indeterministic world: As Russell states, 'the total set of natural conditions affecting some process [on the quantum level], and thus the total possible set of conditions which science can discover and describe through its equations, are necessary but insufficient to determine the precise outcome of the process. The future is ontologically open, influenced but under-determined by the factors of nature acting in the present' (Russell 1998: 203).

\section{Laws of Nature Reconsidered}

The discussion concerning the scope of the laws of nature often puts the cart before the horse. The only reason to assume that the laws of nature are exceptionless in respect to their predictive and explanatory power is that one yet already assumes that they are descriptions of physical processes in a world devoid of freedom and intervention. Of course, 
if right from the start one assumes that there can be laws of nature if and only if there is no freedom, then genuine interventions in the actual world that are not covered by the laws of nature would destroy the very plausibility of our understanding of the fundamental nature of the actual world. However, if we suppose that laws of nature are ceteris paribus descriptions of idealized systems the actual predictive and explanatory power of which depends on whether there is an intervention, then the problem vanishes at once. Although there are laws of nature that regulate what happens in the actual world, not everything that happens is regulated by the laws of nature. ${ }^{18}$

\section{Evidence Reconsidered}

Although there is no positive scientific evidence that the obtaining of a certain state of affairs $S$ is due to special divine action, there is neither scientific evidence that the obtaining of a state of affairs $S^{*}$ is due to free will. All this, though, is only a problem if one assumes the following further principle: if there is no scientific evidence for $p$, then $p$ does not exist. However, since this assumption is not a scientific assumption itself, and since there are no convincing arguments to adopt such a restrictive and positivistic philosophy of science, it follows that there is no need for the Christian to share it.

Apart from the fact that the absence of scientific evidence for special divine action is not sufficient to draw the conclusion that there is no special divine action, there is another reason according to which science could not even in principle provide evidence for special divine action: scientific research assumes that, by definition, 'anything that can move a physical thing is itself a physical thing (although perhaps a strange and heretofore unstudied kind of physical thing)' (Dennett 1991: 35). As Lowe states the same point, physics assumes that 'anything which can exert a force on physical objects, that is, which can do work on a physical system, is ipso facto something "physical" and the force it exerts is consequently a "physical" one. The very definition of the "physical" [...] is that it is something capable of exerting force, or equivalently of doing work or contributing energy to a system' (Lowe 1996: 61). If this is true, then by definition physics cannot discover anything that from a metaphysical point of view could be addressed as a special divine action.

\footnotetext{
${ }^{18}$ Cf. Foster (1934: 465).
} 


\section{Evil Reconsidered}

The problem of evil is the most pressing one. Whereas normally the existence of evil and suffering is used to show that an omnipotent, omniscient, and morally perfect being cannot be the creator of the actual world, our discussion of the argument is based on the assumption that such a being exists. A defence of the possibility of special divine action therefore has to show that either there is no unnecessary evil and suffering in the world or else has to show that there is no moral obligation to prevent the existence of unnecessary evil and suffering. Since it seems to be a conceptual truth that an omnipotent, omniscient and morally perfect creator of the world would prevent unnecessary evil and suffering - that is, suffering that serves no purpose at all - it seems plausible for the Christian philosopher to reject the assumption that there is unnecessary evil and suffering in the world.

If there is no unnecessary evil and suffering, then it follows that every occurring evil and suffering has a purpose. Whereas some may argue that this is a cynical conclusion given the huge amount of suffering and evil in the world that appears to us to be without a purpose, the Christian philosopher can point out that in God's providential plan no one, ultimately, suffers without a purpose. This seems to be an existentially tenable view of the world if the alternative is a naturalistic and atheistic worldview according to which people suffer without no purpose at all.

\section{The Possibility of Special Divine Action}

None of the arguments presented against the possibility of special divine action is decisive. The argument from determinism is not sound because science itself supposes that the world is indeterministic. The argument from laws of nature, the argument from evidence, and the argument from causal closure are not sound because they presuppose a philosophy of science that is attractive only for those yet already operating in an atheistic and naturalistic framework. The argument from evil supposes that there is suffering and evil without a purpose, an assumption that the Christian does not of necessity share. In sum, then, although there are prima facie sound arguments against the possibility of special divine action, none of the arguments is ultimately convincing. Christians can firmly believe in the possibility of special divine action without contradicting science or metaphysics. 
Acknowledgement. Thanks to Andrew Pinsent, Stephen Priest, Ignacio Silva, and Anna Sindermann for their comments on an earlier draft of this paper. Research for this paper was funded by the John Templeton Foundation's project "Special Divine Action."

\section{BIBLIOGRAPHY}

Alston, William P. 1999. 'Divine Action, Human Freedom, and the Law of Nature', in Robert John Russell, et al. (eds), Quantum Cosmology and the Laws of Nature: Scientific Perspectives on Divine Action (Vatican: Vatican Observatory Publications), pp. 185-206

Clayton, Philip. 2008. Adventures in the Spirit: God, World, Divine Action (Minneapolis: Fortress Press)

Cobb, John B. 1973. 'Natural Causality and Divine Action', Idealistic Studies, 3: 207-222

Craver, Carl F. 2007. 'Structures of Scientific Theories', in Peter Machamer and Michael Silberstein (eds), The Blackwell Guide to the Philosophy of Science (Oxford: Blackwell Publishing), pp. 55-79

Dennett, Daniel. 1991. Consciousness Explained (New York: Back Bay Books) Earman, John. 1986. A Primer on Determinism (Dordrecht: D. Reidel Publishing) Foster, Michael B. 1934. 'The Christian Doctrine of Creation and the Rise of Modern Science', Mind, 43: 446-468

Göcke, Benedikt Paul. 2008. 'Physicalism Quaerens Intellectum', The Philosophical Forum, 39 (4): 463-468

Göcke, Benedikt Paul. 2013. 'An Analytic Theologian's Stance on the Existence of God', European Journal for Philosophy of Religion, 5 (2): 129-146

Göcke, Benedikt Paul. 2014. A Theory of the Absolute (Basingstoke: Palgrave Macmillan)

Göcke, Benedikt Paul. 2015. 'Did God do it? Metaphysical Models and Theological Hermeneutics', International Journal for Philosophy of Religion, 78 (2): 215-231

Griffin, David Ray. 2014. Panentheism and Scientific Naturalism: Rethinking Evil, Morality, Religious Experience, Religious Pluralism, and the Academic Study of Religion (Claremont, California: Process Century Press)

Hume, David. 1848. Philosophical Essays concerning Human Understanding (London: A. Millar)

Kraay, Klaas J. 2008. 'Can God choose a world at random?', in Yujin Nagasawa and Eric Wielenberg (eds), New Waves in Philosophy of Religion (Basingstoke: Palgrave Macmillan), pp. 22-35

Laplace, P.-S. 1951. A Philosophical Essay on Probabilities (New York: Dover) 
Lowe, E. J. 1996. Subjects of Experience (Cambridge: Cambridge University Press)

Lowe, E. J. 2008. Personal Agency: The Metaphysics of Mind and Action (Oxford: Oxford University)

Mautner, Gareth (ed.). 1996. A Dictionary of Philosophy (Oxford: Blackwell)

Murphy, Nancey. 1995. 'Divine Action in the Natural Order: Buridan's Ass and Schröder's Cat', in Robert John Russell (ed.), Chaos and Complexity: Scientific Perspectives on Divine Action (Vatican: Vatican Observatory Publications), pp. 325-357

Papineau, David. 2000. 'The Rise of Physicalism', in M. W. F. Stone and Jonathan Wolff (eds), The Proper Ambition of Science (London: Routledge)

Papineau, David. 2002. Thinking about Consciousness (Oxford: Oxford University Press)

Perler, Dominik, and Ulrich Rudolph. 2000. Occasionalismus: Theorien der Kausalität im arabisch-islamischen und im europäischen Denken (Göttingen: Vandenhock \& Ruprecht)

Plantinga, Alvin. 2011. Where the Conflict Really Lies: Science, Religion, and Naturalism (Oxford: Oxford University Press)

Polkinghorne, John C. 2006. 'Christianity and Science', in Philip Clayton and Zachary Simpson (eds), The Oxford Handbook of Religion and Science (Oxford: Oxford University Press), pp. 57-70

Pollard, William G. 1958. Chance and Providence: God's Action in a World Governed by Scientific Law (London: Faber and Faber)

Russell, Robert John. 1998. 'Special Providence and Genetic Mutation: A New Defense of Theistic Evolution', in Robert John Russell, et al. (eds), Evolutionary and Molecular Biology: Scientific Perspectives on Divine Action (Vatican: Vatican Observatory Publications), pp. 191-223

Saunders, Nicholas T. 2000. 'Does God Cheat at Dice? Divine Action and Quantum Possibilities', Zygon, 35 (3): 517- 544

Schaffer, Jonathan. 2007. 'Deterministic Chance?', British Journal for the Philosophy of Science, 58: 113-140

Schwöbel, Christoph. 1992. God: Action and Revelation (Kampen: Kok Pharos) Ward, Keith. 2007. Divine Action (Conshohocken: Templeton Foundation Press) Wegter-McNelly, Kirk. 2009. 'Fundamental Physics and Religion', in Philip Clayton and Zachary Simpson (eds), The Oxford Handbook of Religion and Science (Oxford: Oxford University Press), pp. 156-171 